\title{
PATIENT AND PARENT MOTIVATION FOR ORTHODONTIC TREATMENT AND AGREEMENT BETWEEN ORTHODONTIST, PARENT, PATIENT PERCEPTION USING IOTN AC
}

\author{
Donata Petronyte் $\dot{1}^{1}$ Giedrẻ Trakinien $\dot{e}^{2}$ \\ ${ }^{I}$ Dentist, General Practitioner, ${ }^{2}$ Department of Orthodontics, \\ Lithuanian University of Health Sciences, Kaunas, Lithuania
}

Key words: index of orthodontic treatment need aesthetic component (IOTN AC), motivating factors, perception of malocclusion, patient's and parent's, orthodontics.

\begin{abstract}
Summary
Objectives. Key motivating factors for getting an orthodontic consultation of orthodontic patients up to 18 years old together with their parents, as well as fears, relating to orthodontic treatment, were evaluated during the research study. A subjective evaluation of aesthetic component was performed by parents, children and the orthodontist.

Material and Methods. After obtaining the permit of the Bioethics Centre (No. BEC- OF- 804) in LSMUL KK Orthodontic clinic, patients and parents, who came to the initial consultation, were interviewed. Patients and parents were selected by a random sampling. Research subjects received 2 separate questionnaires, which were filled in by patient himself, his parents. Furthermore, the aesthetic component of the patient was evaluated by the patient, his parents and the examiner. Data analysis was performed using a statistical SPSS 22 package. Significance level 0.05 was chosen.

Results. Key motivating factor for orthodontic treatment was aesthetic in the group of patients and parents. The majority of children and parents, who took part in the research, do not have any fears relating to orthodontic treatment. Patients appear to evaluate condition of their teeth more positively than their parents $(p<0.05)$. Both parents and children evaluate condition of teeth more positively than the examiner $(\mathrm{p}<0.05)$.

Conclusions. The aesthetic factor remains the most important motivation for orthodontic treatment; there is usually no fear, relating to orthodontic treat-
\end{abstract}

ment, present at the beginning of the treatment. There is a significant difference of subjective aesthetic evaluation of teeth condition between subjects and the orthodontist.

\section{Introduction}

Malocclusion can be considered a public health problem due to its high prevalence. A number of studies have demonstrated its impact on a quality of life and it's considered the third highest oral health priority by the World Health Organization [1]. Functional damage due to malocclusion can lead to dental injuries, dental caries, periodontal diseases, sleep related breathing and chewing disorders, moreover it can be associated with a development of dyslexia [1-3].

Some particular types of malocclusion seem to affect a satisfaction level with one's dental, facial appearance, general appearance and perceived attractiveness [4]. Optimal facial appearance is not only viewed as being more attractive but it is also more socially accepted by peers, teachers, employers and others. Smiling is still considered to be one of the most effective methods of influencing people [5]. Attractive people are perceived as friendly, intelligent, interesting, more social and much more positive personalities in general [2].

Most orthodontic patients are children and adolescents. It is assumed that an irregular set of teeth and less aesthetic face can negatively affect a child. The child is then a target of jibes and is given nicknames and so forth [2]. Some individuals with dentofacial disharmonies who are seeking treatment usually experience some level of psychological distress that may warrant psychological intervention [5].

Self-perception of malocclusion and the uptake of orthodontic treatment have been studied among several groups of population [6,7]. Gender, age, intellectual level, social group, the degree of defect, and perception of one's own facial aesthetics can also relate to the desire to undergo 
orthodontic treatment or to provide it to one's child [2].

The concept of Erik Erikson [8], who views childhood as a series of stages, is wildly accepted in the field of child development. According to his theory, there are certain age specific tasks within each stage of childhood. He has separated a psychological management of the patient by specific age groups: $6-9 ; 10-13 ; 14-18$ year. According to some other studies, it has been suggested that 14-17-yearold youths are identified as the most vulnerable with regard to their psychological well-being and higher levels of pain tolerance during the phases of treatment. Younger people, 11-13 year olds, can cope better with their ability to chose to wear orthodontic appliancie. However, previous studies regarding a decision-making have suggested that children under ages 10-12 rarely do seem to be capable of making decisions on aesthetic improvements by themselves [9].

Decisions to provide and accept an orthodontic treatment are not defined by orthodontists only. They are arrived at by the negotiation between all interested parties - the child, parents, dentist, orthodontists and payment agencies [10]. It is important to determine prior to the treatment both the patients and their parents (guardians) motivations and expectations of the treatment [5].

Patients' cooperation is an essential factor for the timely and successful outcome of an orthodontic treatment. A lack of cooperation may lead to a significant effect on the period of time a patient must wear orthodontic appliances [11].

Patients self-perception is extremelly important in determining between the treatment demand and cooperation while parents are the most powerful single factor in the motivation for treatment. Several studies have investigated the relationship between the objective need of an orthodontic treatment and the subjective patient and parent perceptions of malocclusion [11].

Therefore, the aim of this study is to evaluate patients' under age 18 and their parents or guardians motives for choosing an orthodontist, fear factors when it comes to the orthodontic treatments and the necessity of the treatment based on the aesthetic index component (IOTN AC).

The aim of this study was to evaluate the motivation of children below 18 years and their parents (guardians) for choosing orthodontist and to establish the fear factors which were associated with the orthodontic treatment and necessity of it based on IONT AC.

\section{Material and methods}

After obtaining a permit from the Bioethics Centre (No. BEC- OF- 804) at the Orthodontic clinic, patients and their parents/guardians, who came to the preliminary consultation, were interviewed. All subjects were Lithuanians.
Inclusion criteria into the study group were: 1) patient's younger than $18 \mathrm{yrs}$ who came in with their parents/guardians for the preliminary consultation; 2) those who have agreed to participate in the study; 3 ) patients who have no mental disorders. This study was conducted from May 1, 2015 to December 1, 2015.

Research subjects received 2 separate questionnaires, which were filled in by the patient himself/herself and his/ her parent's (guardian's). Parent's (guardian's) questionnaire consisted of three parts: the first part consisted of the questions related to the demographic aspect, the second part was made of the questions and aesthetic component evaluation photos according to IOTN requirements, and the third part was designed to evaluate parents'(guardian's) approaches to an orthodontic treatment. Patients' questionnaire consisted of two parts: accurate indication of their age and the same questions as in the second part of their parent's (guardian's) questionnaire. Patients and their parent's (guardian's) were selected by a random sampling. The subjects could, if applicable, select more than one answer to each question.

Measurement of aesthetics. An orthodontic treatment need was determined using the Index of Orthodontic Treatment Need (IOTN). The IOTN is an internationally acknowledged scoring system for an orthodontic treatment need as perceived by the professionals and patients. The IOTN incorporates both a Dental Health Component (DHC; Brook and Shaw, 1989) and an aesthetic component (AC; Evans and Shaw, 1987) [12]. For this study only the $\mathrm{AC}$ was used.

The AC was scored both by the patients, parents and by the orthodontists independently. Parents were asked to make a judgement about how severe they considered their child's dental attractiveness. The patients were also assessing their own occlusions using the same scale (AC of the IOTN) and rated their occlusions according to the photographs which most closely matched the attractiveness of their own teeth.

The grades of the $\mathrm{AC}$ which corresponded to the numbers on the respective photographs, depicting the levels of the treatment need were as follows:

AC Grades 1- 4: No need for orthodontic treatment.

AC Grade 5-7: Borderline / Moderate need for orthodontic treatment.

AC Grade 8-10: Definite need for orthodontic treatment.

Two researchers carried out the assessment of the 229 non-adult patients who matched the IOTN AC assessment criteria twice - at the beginning and at the end of the study. Patients were not photographed.

Statistical analysis. The obtained data was analyzed 
using the statistical Package for Social Sciences (version 20.0, SPSS, Chicago, Ill) program. Parametric data were expressed as

Table 1. Characteristics of patients

\begin{tabular}{|l||l|l||l|l|}
\hline \multicolumn{2}{|c|}{} & \multicolumn{2}{c|}{ Number (n) } & \multicolumn{2}{c|}{ Percentage (\%) } \\
\hline Age (years) & Female & Male & Female & Male \\
\hline $6-9$ & 45 & 29 & 32.4 & 32.2 \\
\hline $10-13$ & 67 & 40 & 48.2 & 44.5 \\
\hline $14-18$ & 27 & 21 & 19.4 & 23.3 \\
\hline Total & $\mathbf{1 3 9}$ & $\mathbf{9 0}$ & & \\
\hline
\end{tabular}

Table 2. The reasons for coming to the orthodontist - responses of the patients.

Statistically significant depending on the patient's *age and ${ }^{* *}$ gender ( $p<0.05$, Chi squares test). The selected answer: $a$ - I have "irregular teeth; $b$ - The other children laugh at my "irregular teeth"; c-I cannot chew normally; $d$-I have some difficulties while: speaking; $e$ - I breath though the mouth; $f$-I'm afraid to smile; $g$-My parents wanted me to be treated, $h$-Other reasons.

\begin{tabular}{|c|c|c|c|c|c|c|}
\hline $\begin{array}{l}\text { The } \\
\text { selected } \\
\text { answer }\end{array}$ & $\begin{array}{c}6-9 \\
\text { n (\%) }\end{array}$ & $\begin{array}{l}10-13 \\
\mathrm{n}(\%)\end{array}$ & $\begin{array}{l}14-18 \\
\mathrm{n}(\%)\end{array}$ & \multicolumn{2}{|c|}{$\begin{array}{c}\text { F/M } \\
\mathrm{n}(\%)\end{array}$} & $\mathrm{P}$ value \\
\hline A & $50(33.1)$ & $66(43.7)$ & $35(23.2)$ & $96(63.6)$ & $55(36.4)$ & 0.370 \\
\hline B & $6(46.2)$ & $6(46.2)$ & $1(7.7)$ & $6(42.6)$ & $7(53.8)$ & $\begin{array}{l}0.21 \\
0.372 \\
0.269\end{array}$ \\
\hline $\mathrm{C}$ & $8(72.7)$ & $2(18.2)$ & $1(9.1)$ & $6(54.5)$ & $5(45.5)$ & $* 0.013$ \\
\hline $\mathrm{D}$ & $7(38.9)$ & $9(50)$ & $2(11.1)$ & $13(72.2)$ & $5(27.8)$ & $\begin{array}{l}0.546 \\
0.297\end{array}$ \\
\hline $\mathrm{E}$ & $28(63.6)$ & $15(34.1)$ & $1(2.3)$ & $28(63.6)$ & $16(36.4)$ & $\begin{array}{l}* \mathbf{0 . 0 0 0 5} \\
0.657\end{array}$ \\
\hline F & $19(25.7)$ & $36(48.6)$ & 19(25.7) & $53(71.6)$ & $21(28.4)$ & $\begin{array}{l}0.254 \\
* * 0.019\end{array}$ \\
\hline G & $64(53.8)$ & $47(39.5)$ & $8(6.7)$ & $69(58)$ & $50(42)$ & $\begin{array}{l}* \mathbf{0 . 0 0 0 5} \\
0.382\end{array}$ \\
\hline $\mathrm{H}$ & $3(10)$ & $18(60)$ & $9(30)$ & $17(56.7)$ & $13(43.3)$ & $\begin{array}{l}* \mathbf{0 . 0 1 9} \\
0.628\end{array}$ \\
\hline
\end{tabular}

Table 3. The reasons for coming to the orthodontist-responses of the parent's/guardian's.

Statistically significant depending on the patient's *age ( $p<0.05$, Chi squares test). The selected answer: $a$ - My children have "irregular teeth"; $b$ - The other children laugh at my children; $c$ Children cannot chew normally; $d$-Children have some difficulties while: speaking; e-Children breath though the mouth; $f$-Children afraid to smile; $g$ - I wanted my children be treated; $h$-Other reasons.

\begin{tabular}{|c|c|c|c|c|c|c|}
\hline \multirow{3}{*}{$\begin{array}{l}\begin{array}{l}\text { The } \\
\text { selected } \\
\text { answer }\end{array} \\
\text { A }\end{array}$} & \multicolumn{5}{|c|}{ 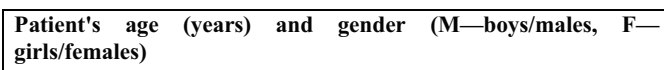 } & \multirow[b]{2}{*}{$\mathrm{P}$ value } \\
\hline & $\begin{array}{c}6-9 \\
\mathrm{n}(\%)\end{array}$ & $\begin{array}{l}10-13 \\
\mathrm{n}(\%)\end{array}$ & $\begin{array}{l}14-18 \\
\mathrm{n}(\%)\end{array}$ & \multicolumn{2}{|c|}{$\begin{array}{c}\mathrm{F} / \mathrm{M} \\
\mathrm{n}(\%)\end{array}$} & \\
\hline & $45(34.6)$ & $58(44.6)$ & $27(20.8)$ & $82(63.1)$ & \begin{tabular}{|l|l|}
$48(36.9)$ \\
\end{tabular} & $\begin{array}{l}0.676 \\
0.398\end{array}$ \\
\hline B & $1(12.5)$ & $3(37.5)$ & $4(50)$ & $5(62.5)$ & $3(37.5)$ & $\begin{array}{l}0.106 \\
0.915\end{array}$ \\
\hline $\mathrm{C}$ & $7(58.3)$ & $4(33.3)$ & $1(8.3)$ & $5(41.7)$ & $7(58.3)$ & $\begin{array}{l}0.129 \\
0.166\end{array}$ \\
\hline $\mathrm{D}$ & $4(44.4)$ & $4(44.4)$ & $1(11.1)$ & $4(44.4)$ & $5(55.6)$ & $\begin{array}{l}0.647 \\
0.308\end{array}$ \\
\hline $\mathrm{E}$ & $12(41.4)$ & $14(48.3)$ & $3(10.3)$ & $17(58.6)$ & 12(41.4) & $\begin{array}{l}0.266 \\
0.806\end{array}$ \\
\hline $\mathrm{F}$ & $2(5.7)$ & $16(45.7$ & $17(48.6)$ & $26(74.3)$ & $9(25.7)$ & $\begin{array}{l}* \mathbf{0 . 0 0 0 5} \\
0.074\end{array}$ \\
\hline G & 51(34) & $68(45.3)$ & $31(20.7)$ & \begin{tabular}{|l|}
$93(62)$ \\
\end{tabular} & $57(38)$ & $\begin{array}{l}0.748 \\
0.579\end{array}$ \\
\hline $\mathrm{H}$ & $15(33.3)$ & $20(44.4)$ & $10(22.2)$ & $25(55.6)$ & \begin{tabular}{|l|}
$20(44.4)$ \\
\end{tabular} & $\begin{array}{l}0.940 \\
0.431\end{array}$ \\
\hline
\end{tabular}

mean and standard deviation (M [SD]). P value less than 0.05 was regarded to indicate statistical significance. Chi-square test $\left(\chi^{2}\right)$ was used to compare qualitative variables based on cross tabulation. Student's t-test was used. Kappa coefficient was used to compare two examiners coincidence of survey data.

\section{Results}

A total of 229 patients participated in the study: $139(60.7 \%)$ girls and $90(39.3 \%)$ boys. The average children age - 11.72 (2.79) (Table 1.).

A total of 229 parents and guardians of the patients participated in the study: 194 (85\%) mothers, $20(9 \%)$ fathers and $15(6 \%)$ guardians. The average parent or guardian age $-39.48(6.84)$. The distribution by their education level is secondary (23\%), special secondary (19\%), higher non-university (22\%), higher education university type $(36 \%)$.

The majority of patients selected aesthetics as the main reason for their decision to undergo orthodontic treatment (Table 2).

6- 9 years old patients did focus on the functional aspects (ex: difficulty chewing, breathing) (Table 2: answer c, e). Also children of this age are not yet sufficiently independent (Table 2 : answer g). 10-13 year old girls more than boys afraid about teeth apperance (Table 2: answer f).

The majority of parents selected aesthetics as the main reason for their decision to undergo orthodontic treatment (Table 3: answers a, g). Parents and guardians considered that 10- 13 and 14- 18 year old patient often worry about his/her teeth apperance especially girls. (Table 3 : answers $\mathrm{f}$ )

It seems that 14- 18 year old patients don't worry about orthodontic appliances and social judgments. (Table 4: answer a, d).

Parents and guardians are considered that there is usually no fear, relating to orthodontic treatment (Table 5: answer e).

48 patiens were examined by one of the examiners and then re-examined by the other examiner after consultation. This procedure resulted in an inter-examiner reliability with a Kappa value of 0.585 , representing as "moderate" agreement between examiners.

In assessing the aesthetic component based on the scale of the teeth photos, it was determined that regardless of the patient 's willingness to have orthodontic treatment, they assess their own dental 
Table 4. A distribution of patient's responses to the question "Do you think there are any reasons why you would not want to "straighten" your teeth?"

Statistically significant depending on the patient's *age ( $p<0.05$, Chi squares test). The selected answer: $a$ - Because you may need to wear a plate or braces; $b$ - Orthodontic appliances isn't comfortable; c-It can be painful; $d$-My peers may mock me; e-Other reasons.

\begin{tabular}{|c|c|c|c|c|c|c|}
\hline $\begin{array}{l}\text { The } \\
\text { selected } \\
\text { answer }\end{array}$ & $\begin{array}{c}\text { 6- } 9 \\
\text { n (\%) }\end{array}$ & $\begin{array}{l}10-13 \\
\text { n (\%) }\end{array}$ & $\begin{array}{l}14-18 \\
\text { n (\%) }\end{array}$ & \multicolumn{2}{|c|}{$\begin{array}{l}\text { F/M } \\
\mathrm{n}(\%)\end{array}$} & $\mathrm{P}$ value \\
\hline A & $27(44.3)$ & $28(45.9)$ & $6(9.8)$ & $35(57.4)$ & 26(42.6) & $\begin{array}{l}\mathbf{* 0 . 0 1 4} \\
0.535\end{array}$ \\
\hline B & $17(36.2)$ & $20(42.6)$ & $10(21.3)$ & $28(59.6)$ & $19(40.4)$ & $\begin{array}{l}0.781 ; \\
0.860\end{array}$ \\
\hline C & $21(38.9)$ & $25(46.3)$ & $8(14.8)$ & $33(61.1)$ & $21(38.9)$ & $\begin{array}{l}0.329 \\
0.943\end{array}$ \\
\hline $\mathrm{D}$ & $11(50)$ & $11(50)$ & 0 & \begin{tabular}{|l|}
$14(63.6)$ \\
\end{tabular} & $8(36.4)$ & $\begin{array}{l}\text { *0.023 } \\
0.767\end{array}$ \\
\hline $\mathrm{E}$ & $42(34.1)$ & $53(43.1)$ & $28(22.8)$ & $75(61)$ & $48(39)$ & $\begin{array}{l}0.487 \\
0.926\end{array}$ \\
\hline
\end{tabular}

Table 5. A distribution of parent, $\mathrm{s}$ and guardian ,s responses to the question "Do you think there are any reasons why your child would not want to "straighten" their teeth?". $N(\%)$ of the selected (by parent 's/ guardian 's) answers.

Statistically significant depending on the patient's *age ( $p<0.05$, Chi squares test). The selected answer: $a$-Because your children may need to wear a plate or braces; $b$-Orthodontic appliance isn't comfortable; $c$ - It can be painful; $d$ - Children peers may mock; $e$ - Other reasons.

\begin{tabular}{|c|c|c|c|c|c|c|}
\hline \multirow{3}{*}{$\begin{array}{l}\text { The } \\
\text { selected } \\
\text { answer } \\
\text { A }\end{array}$} & \multicolumn{5}{|c|}{$\begin{array}{llllll}\begin{array}{l}\text { Patient's age } \\
\text { girls/females })\end{array} & \text { (years) } & \text { and } & \text { gender } & (M-b o y s / \text { males, } & F- \\
\end{array}$} & \multirow[b]{2}{*}{$P$ value } \\
\hline & $\begin{array}{c}6-9 \\
\mathrm{n}(\%)\end{array}$ & $\begin{array}{l}10-13 \\
\mathrm{n}(\%)\end{array}$ & $\begin{array}{l}14-18 \\
\mathrm{n}(\%)\end{array}$ & $\begin{array}{l}\mathrm{F} / \mathrm{1} \\
\mathrm{n}\left({ }^{9}\right.\end{array}$ & & \\
\hline & $15(28.3)$ & $28(52.8)$ & 10(18.9) & \begin{tabular}{|l|}
$27(50.9)$ \\
\end{tabular} & $26(49.1)$ & $\begin{array}{l}0.595 \\
0.097\end{array}$ \\
\hline B & $21(38.9)$ & $25(46.3)$ & $8(14.8)$ & $31(57.4)$ & $23(42.6)$ & $\begin{array}{l}0.329 \\
0.571\end{array}$ \\
\hline $\mathrm{C}$ & $21(42.9)$ & $21(42.9)$ & $7(14.3)$ & $30(61.2)$ & 19(38.8) & $\begin{array}{l}0.160 \\
0.932\end{array}$ \\
\hline $\mathrm{D}$ & $8(29.6)$ & $14(51.9)$ & $5(18.5)$ & $17(63)$ & $10(37)$ & $\begin{array}{l}0.849 ; \\
0.798\end{array}$ \\
\hline $\mathrm{E}$ & $33(29.7)$ & $47(42.3)$ & $31(27.9)$ & $70(63.1)$ & $41(36.9)$ & $\begin{array}{l}* \mathbf{0 . 0 4 2} \\
0.477\end{array}$ \\
\hline
\end{tabular}

condition way better than their parents or guardians are $(\mathrm{p}<0.05)$. Mothers assess the patients dental condition way worse than the patients are $(p<0.0005)$. Parents and patients assess the condition of their teeth better than the individual conducting the study $(\mathrm{p}=0.012)$ (Figure 1-2).

\section{Discussion}

The main factors which imply patients to seek orthodontic treatment can be aesthetical considerations and functional disturbances. The results of this study revealed that the main motivating factor for patients and their parents or guardians to undergo orthodontic treatment was the appearance of their teeth. These findings matched with the results of Samsonyanova L. and Broukal Z. studies [2]. Futhermore, authors agree that importance of nice smile is not same during the childhood [13].

Younger patients more often than older ones used a statement "My parents want my teeth to be "straight." It can be argued that

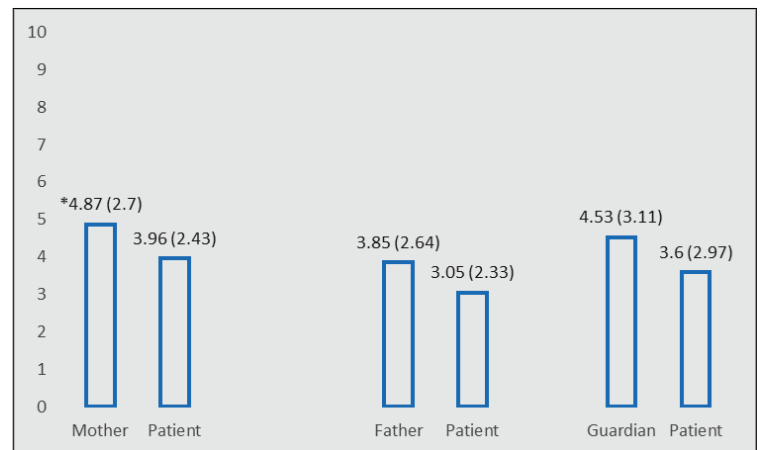

Figure 1. Frequency of orthodontic treatment need required $P$ value considered significant when $\mathrm{P}<0.05$ by Chi-squares test.

* Statistically significant mean (SD).

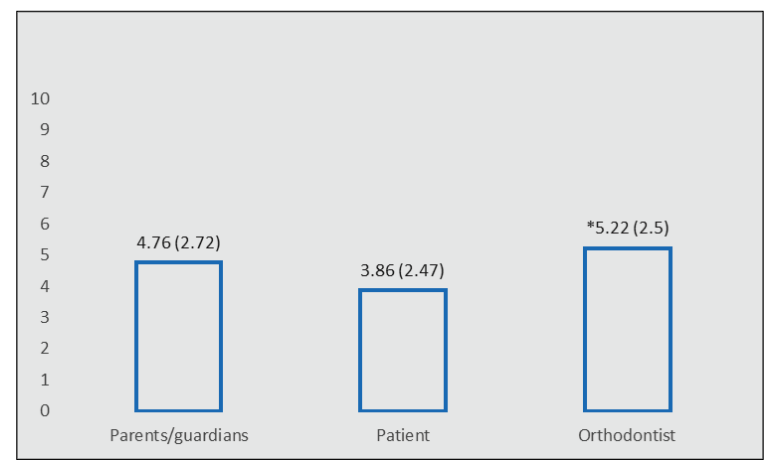

Figure 2. Difference between orthodontist, parent and patient IOTN-AC

$P$ value considered significant when $P<0.05$ by Chi-squares test. * Statistically significant mean (SD).

children of this age are not yet sufficiently independent, their logical thinking is still evolving and they find it difficult to deal with hypothetic, abstract problems [14].

While analyzing problems with biting, chewing, temporomandibular disorders and headache several studies have been reported as reasons for seeking professional advice [5]. In the study of Marques L. S. et al. [1] found that functional aspects (difficulty chewing or speaking) were more important than aesthetic aspects (ex: crowding) in the determination of the importance of orthodontic treatment. Patients and their parents or guardians of this study did not focus on the functional aspects of orthodontic treatment as it was supported in the study of Wędrychowska-Szulc B. and Syryńska M [5]. It was found that younger patients (ages 6-10) complained of breathing through the mouth more often than the older ones. However, it is worth noting that lymphoid tissue flourishes for the children between ages 9-10 and at that time respirato- 
ry alterations such as breathing though the mouth become very common. According to Nurminen et al. and Trulsson et al. [5] functional reasons were reported by 47-68 per cent of patients who had undergone orthognathic surgery.

Most of the previous studies have shown that parents motivation was the most important factor in initiating orthodontic treatment and the treatment is considered to be more important for the parents than for the child (Birkeland et al.; Bergström et al.; Daniels and Richmond; Kerosuo et al.; Hamdan; Zhang et al.). Thus, parents appear to make the final decision about treatment, although they may have different motives compared to their children [5].

$84.72 \%$ of the participants were mothers. According to Miner et al. [2], mothers perceptions are the primary motivating factors for seeking orthodontic treatment.

Abdullah and Rock [7] found that while the orthodontist scored $22.8 \%$ of children in "Definite Treatment Need" (IOTN-AC $8-10$ ), $5.8 \%$ of children and $4.8 \%$ of the parents had the same result. Birkeland et al. [7] found that in a sample size of 359 children with a mean age of 10.6 years, $53.2 \%$ had moderate to severe treatment need, as per the normative need, while self-perception was inclined towards mild treatment need. Aikins et al. [6] found self perception to be IOTN-AC Grade $1-4$ as well $(\mathrm{n}=82.5 \%)$ and the orthodontist's perceived $64.9 \%$ children in the same grade. Kolawole et al. [7] also found that a higher percentage of children perceived their malocclusions on the attractive end of the aesthetic scale (92\%) while the orthodontist found $37.6 \%$ in moderate to definite treatment need.

According Aikin et al. [6], age and gender were not found to influence self- perceived orthodontic treatment need. This study shows the same results. It is probably due to the subjects' general lack of awareness of the presence of malocclusion.

In this study was found that $9,6 \%$ of the study respondents cared about any kind mockery the least which may be associated with a certain trend to wear plates or braces. Tooth movement produced by orthodontic appliances causes discomfort and it has been reported that the fear of pain is a key factor dissuading patients from seeking orthodontic treatment. Younger patients demonstrated greater tolerance and adaptation to discomfort caused by fixed orthodontic appliances [15]. Interestingly, Patel et al. [16] has found that children do not make social judgments about other children purely on the basis of wearing a fixed orthodontic appliance, suggesting that they are viewed as part of a normal dental appearance in adolescence.

\section{Conclusions}

The aesthetic factor is the most important motivation for orthodontic treatment. There is usually no fear, relating to orthodontic treatment, present at the beginning of the treatment. There is a significant difference of subjective aesthetic evaluation of teeth condition between patient, parent and the orthodontist.

\section{References}

1. Marques LS, Pordeus I, Ramos-Jorge M, Filogônio C, Filogônio C, Pereira L, Paiva S. Factors associated with the desire for orthodontic treatment among Brazilian adolescents and their parents. BMC Oral Health 2009 Sep;9:34-41:el. [Medline:20021649] [doi: https://dx.doi.org/10.1186/14726831-9-34]

2. Samsonyanová L, Broukal Z. A systematic review of individual motivational factors in orthodontic treatment: facial attractiveness as the main motivational factor in orthodontic treatment. International Journal of Dentistry 2014:1-7:el. [doi:http:// dx.doi.org/10.1155/2014/938274]

3. Hassan AH, Hassan MH, Linjawi AI. Association of orthodontic treatment needs and oral health-related quality of life in Saudi children seeking orthodontic treatment. Patient preference and adherence 2014 Aug 8:1571-1579. [Medline:4235476] [doi:https://dx.doi.org/10.2147\%2FPPA.S71956 ]

4. Feldens CA, Nakamura EK, Tessarollo FR, Closs LQ. Desire for orthodontic treatment and associated factors among adolescents in southern Brazil. The Angle Orthodontist 2015 Mar;85(2):224-232. [Medline:25045778] [doi:https://dx.doi. org/10.2319/021014-105.1]

5. Wędrychowska-Szulc B, Syryńska M. Patient and parent motivation for orthodontic treatment - a questionnaire study. The European Journal of Orthodontics 2009 Aug;32(4): 447-452. [Medline:20008018] [doi:https://dx.doi.org/10.1093/ejo/ cjp131]

6. Aikins EA, DaCosta OO, Onyeaso CO, Isiekwe MC. Self-perception of malocclusion among Nigerian adolescents using the aesthetic component of the IOTN. The Open Dentistry Journal 2012 Apr 6:61-66. [Medline:22529881] [doi:https://dx.doi.or $\mathrm{g} / 10.2174 / 1874210601206010061]$

7. Siddiqui TA, Shaikh A, Fida M. Agreement between orthodontist and patient perception using Index of Orthodontic Treatment Need. The Saudi Dental Journal 2014 Oct;26(4):156-165. [Medline:4223820] [doi:https://dx.doi.org/10.1016\%2Fj. sdentj.2014.03.004]

8. Norton LA, Markowitz M. Psychological management of the young orthodontic patient. Patient management 1971;41(3):241-248.

9. Trulsson U, Strandmark M, Mohlin B, Berggren U. A qualitative study of teenagers' decisions to undergo orthodontic treatment with fixed appliance. Journal of Orthodontics 2002 Sep;29(3):197-204. [Medline: 12218197] [doi:https://dx.doi. org/10.1093/ortho/29.3.197]

10. Spalj S, Slaj M, Varga S, Strujic M, Slaj M. Perception of orthodontic treatment need in children and adolescents. The 
European Journal of Orthodontics 2009 Oct ; 32(4): 387-394. [Medline: 20008018] [doi: https://dx.doi.org/10.1093/ejo/ cjp131]

11.Danielsa AS, Seacatb JD, Inglehart MR. Orthodontic treatment motivation and cooperation: a cross- sectional analysis of adolescent patient's and parent's responses. American Journal of Orthodontics and Dentofacial Orthopedics 2009 Dem;136(6):780-787. [Medline: 20008018] [doi: https:// dx.doi.org/10.1093/ejo/cjp131]

12.Hamdan AM. The relationship between patient, parent and clinician perceived and normative orthodontic treatment need. The European Journal of Orthodontics Jun 2004; 26(3) 265-271. [Medline: 15222710] [doi: 10.1093/ejo/26.3.265]

13. Lew KK. Attitudes and perceptions of adults towards orthodontic treatment in an Asian community. Community Dent and Oral Epidemiology 1993 Feb;21(1): 31-5. [Medline: 8432102] [doi: 10.1111/j.1600-0528.1993.tb00715.x]

14. Žukauskienė R. Raidos psichologija: integruotas požiūris. Vilnius, 2012; 377- 562.

15. Marques LS, Paiva SM, Vieira-Andrade RG, Pereira LJ, Ramos-Jorge ML. Discomfort associated with fixed orthodontic appliances: determinant factors and influence on quality of life. Dental Press Journal of Orthodontics 2014 May-Jun; 19(3):102-107. [Medline: 4296617] [doi:10.1590/21769451.19.3.102-107.oar.]

16. Patel. A, Rodd HD, Baker SR, Marshman Z, Robison PG, Benson PE. Are social judgements made by children in relation to orthodontic appliances? Jounal of Orthodontics 2010 Feb; 37(2):93-99. [Medline: 20567032] [doi: https://dx.doi. org/10.1179/14653121042948]

\section{PACIENTO IR TE்VŲ MOTYVACIJA ORTODONTINIAM GYDYMUI IR SUDERINAMUMAS TARP ORTODON- TO, TĖVŲ IR PACIENTO NAUDOJANTIS IOTN EKD} Petronytė, G. Trakinienė

Raktažodžiai: gydymo reikalingumo indekso estetinis komponentas (IOTN EK), motyvaciniai veiksniai, netaisyklingo sąkandžio suvokimas, pacientai ir tèvai, ortodontija.

\section{Santrauka}

Problemos aktualumas ir darbos tikslas. Tyrimo metu buvo vertinti ortodontinių pacientų iki 18 metų ir jų tėvų ar globejjų pagrindiniai motyvaciniai veiksniai atvykti ortodonto konsultacijai; ortodontinio gydymo baimès. Be to, buvo atliekamas subjektyvus estetinio komponento ịvertinimas tarp tėvų ir vaikų bei tiriančio asmens.

Medžiaga ir metodai: Gavus bioetikos centro leidimą ( $\mathrm{Nr}$. BEC- OF- 804), LSMUL KK Ortodontijos klinikoje buvo apklausti pacientai bei jų tẻvai ar globejjai, atvykę i pirminę konsultaciją. Pacientai ir jų tèvai ar globejjai pasirinkti atsitiktinès atrankos būdu. Tiriamiesiems buvo pateikti 2 atskiri klausimynai, kuriuos pildè pacientas, jo tèvai ar globejai. Taip pat buvo vertinamas paciento, estetinis komponentas tarp paciento, jo tėvų ar globėjų bei tiriančio asmens. Duomenų analizè atlikta, naudojant statistinị SPSS 22 paketą. Pasirinktas reikšmingumo lygmuo 0.05 .

Rezultatai. Pagrindinis motyvacinis veiksnys pacientų ir tėvų ar globėjų grupeje ortodontiniam gydymui buvo estetinis. Dauguma tyrime dalyvavusių vaikų ir tėvų ar globėjų nejaučia ortodontinio gydymo baimès. Pacientai savo dantų būklę vertina geriau nei jų tèvai ar globėjai $(\mathrm{p}<0.05)$, mamos vertina vaikų dantis blogiau nei vaikai $(p<0.05)$. Tèvai ir vaikai dantų būklę vertina geriau nei tiriantysis $(\mathrm{p}<0.05)$.

Išvados. Estetinis veiksnys išlieka svarbiausia motyvacija ortodontiniam gydymui; gydymo pradžioje dažniausiai nejaučiama baimé, susijusi su ortodontiniu gydymu. Reišmingas subjektyvus dantų būklès estetinio vertinimo skirtumas tarp tiriamųjų ir tirančiojo.

Adresas susirašinėti: donata.petronytee@gmail.com

Gauta 2017-01-24 